\title{
Etiological evaluation of the elevated transaminases in children
}

\section{Transaminaz yükksekliğgi olan çocuklarda etyolojik değerlendirme}

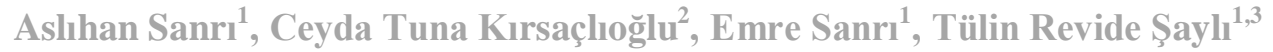

${ }^{1}$ Department of Pediatrics, ${ }^{2}$ Department of Pediatric Gastroenterology, ${ }^{3}$ Department of Pediatrics Hematology. Turkish Republic Health Ministry, Ankara Child Health Diseases, Haematology Oncology Training and Research Hospital, Ankara, Turkey.

Corresponding author: Aslıhan Sanrı, MD, Turkish Republic Health Ministry, Ankara Child Health Diseases, Haematology Oncology Training and Research Hospital, Ankara, Turkey

E-mail: aslihanaltunoglu@gmail.com

Received/Accepted: July 17, 2019 / April 29, 2020

Conflict of interest: There is not a conflict of interest.

\section{SUMMARY}

Objective: We aimed to determine the etiology of hypertransaminasemia in children, demonstrate the differences according to the age and evaluate course of transaminases.

Method: We retrospectively analyzed the medical records of children who presented with elevated transaminase levels for at least 2 months, aged between 3 months and 18 years, for demographic features, laboratory, radiologic and histopathological findings.

Results: Among total 292 children, 194 (66.4\%) were male and 98 (33.6\%) were female. The mean age was $6.5 \pm 5.4$ years. The $45.9 \%$ of the children had no complaints at presentation. Majority of the patients had mildly elevated transaminases (81.6\%). The most common etiology was nonalcoholic fatty liver disease (NAFLD) $(25.7 \%)$. The NAFLD was more prevelant in patients older than 5 years-old $(\mathrm{p}<0.001)$. The second cause was infectious diseases (97.8\% were viral infections) and more prevelant in patients younger than 2 years-old $(\mathrm{p}=0.043)$. In $34.1 \%$ of the children, no overt cause of hypertransaminasemia was identified. The patients with unidentified etiology were significantly younger, but had higher mean aspartate aminotransferase (AST) levels than the patients in whom the etiology was identified ( $\mathrm{p}=<0.0001, \mathrm{p}=0.008$ respectively). The normalization of transaminases was seen in $40.4 \%$ of the patients at mean $5.4 \pm 4.4$ months. The shortest normalization time was observed in drug related liver injury (DILI) among all other etiologies $(\mathrm{p}=0.015)$.

Conclusions: The most common cause of hypertransaminasemia in childhood were NAFLD and viral infections, which varies by age. A stepwise approachment to hypertransaminasemia leads to early diagnosis. Keywords: Hypertransaminasemia, children, infectious diseases, obesity.

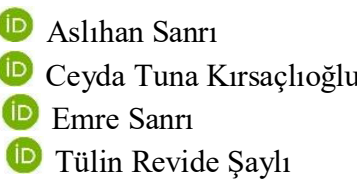

ORCID IDs of the authors: A.S. 0000-0003-1898-0898 C.T.K. 0000-0002-3551-7267 E.S. $0000-0003-2192-3229$ T.R.Ş. 0000-0003-3548-5477

\section{ÖZET}

Amaç: Çocuklarda transaminaz yüksekliğinin etiyolojisini belirlemeyi, yaşa göre farklılıkları göstermeyi ve transaminazların seyrini değerlendirmeyi amaçladık.

Yöntem: En az 2 aydır devam eden transaminaz yüksekliği olan, 3 ay ile 18 yaş arasında çocukların tıbbi kayıtları demografik özellikler, laboratuvar, radyolojik ve histopatolojik bulgular açısından geriye dönük olarak incelendi.

Bulgular: 292 çocuğun 194'ü (\%66.4) erkek ve 98'i (\%33.6) kızdı. Yaş ortalaması 6,5 $\pm 5,4$ yı1 idi. Çocukların \% 45.9 'unun başvuru sırasında herhangi bir aktif şikayeti yoktu. Hastaların \% 81.6'sında transaminaz yüksekliği hafifti. En 
yaygın etiyoloji Non-alkolik yağlı karaciğer hastalığı (NAFLD) (\% 25.7) idi. NAFLD, 5 yaşından büyük hastalarda daha sıktı ( $\mathrm{p}<0.001)$. İkinci en sık neden, enfeksiyöz hastalıklardı (\% 97.8'i viral enfeksiyonlar) ve 2 yaşından küçük hastalarda daha yaygındı $(\mathrm{p}=0.043)$. Çocukların \% 34.1'inde transaminaz yüksekliğinin nedeni tespit edilemedi. Tanımlanamayan etiyolojisi olan hastalar anlamlı olarak daha gençti ve ortalama Aspartat aminotransferaz (AST) düzeyleri daha yüksekti (sırasıyla $\mathrm{p}=<0.0001, \mathrm{p}=0.008$ ). Transaminazların hastaların \% 40.4'ünde ortalama $5.4 \pm 4.4$ ayda normale döndüğü görüldü. Transaminazların en kısa sürede ilaç ilişkili karaciğer hasarında normale döndüğü tespit edildi $(p=0.015)$.

Sonuç: Çocukluk çağında transaminaz yüksekliğinin etyolojisi yaşa göre değişkenlik göstermekte olup en sık nedenler NAFLD ve viral enfeksiyonlardı. Transaminaz yüksekliğine basamaklı yaklaşım erken tanı olanağı sağlamaktadır.

Anahtar sözcükler: Hipertransaminazemi, çocuklar, enfeksiyon hastalıkları, obezite.

\section{INTRODUCTION}

The measurement of serum transaminase levels as a part of the routine biochemical evaluation before surgery or for the investigation of any other conditions, lead to increase the incidental determination of hypertransaminasemia in childhood ${ }^{1}$. Alanine aminotransferase (ALT) and aspartate aminotransferase (AST) are not liverspecific enzymes. So, the elevation of transaminases are not always related to liver disease, but also any other condition such as muscle diseases, genetic/metabolic disorders etc. 1,2 .

There are only a few reports examining the possible causes of hypertransaminasemia in children ${ }^{1,4-8}$. The etiology of hypertransaminasemia varied in different studies according to the selected study population ${ }^{1,4-8}$. When the etiology is determined, follow-up of the transaminase levels is more confident. But the clinical significance and safe follow-up intervals of incidental hypertransaminasemia with unidentified etiology still are not clear.

In present study, we aimed to determine the underlying etiologies of incidentally determined hypertransaminase in children, and to evaluate the severity and the natural course of transaminase levels.

\section{MATERIAL AND METHODS}

We retrospectively reviewed the records of the children for elevated ALT and AST levels who admitted to Turkish Ministry of Health Ankara Child Health and Disease Hematology Oncology Training and Research Hospital pediatric gastroenterology outpatient clinic during January 2010 and January 2013, retrospectively. If AST and/or ALT levels were higher than $40 \mathrm{IU} / \mathrm{L}$, at least twice and persistant for at least 2 months were recruited to the study. Children with incomplete medical records, previously known any chronic diseases including liver and muscle diseases, simultaneous elevated bilirubin levels, whose transmaninase levels normalized within a month and who were hospitalized were excluded from the study. Out of the 390 children with hypertransaminasemia, 292 were met the study criteria.

The records of patients with hypertransaminasemia were reviewed for demographic information, physical examination findings, potential risk factors, family history, presenting symptoms, laboratory findings, abdominal ultrasonography (USG) findings, liver biopsy results, and treatment. Also the outcome of hypertransaminasemia and normalisation time on follow-up were noted.

Potential risk factors were reviewed were presence of an infectious disease during the the last month, drug or herbal usage, and contact to the suspicious material that carry the risk of viral hepatitis transmision.

Serum ALT, AST, gamma-glutamyl transferase (GGT), alkaline phosphatase (ALP) levels, creatine kinase (CK), viral markers, Brucella serology, metabolic screening, ferritin, alpha-1 antityripsin, ceruloplasmin, 24-hour urine copper extraction, autoimmune markers, total immunglobuline (Ig) G, $\mathrm{M}$ and $\mathrm{A}$, tissue transglutaminase $\operatorname{IgA}$, thyroid hormones, sweat chloride test, specific genetic tests results were noted.

The body mass index (BMI) and relative weight were calculated and interpreted according to the literature ${ }^{9,10}$. Diagnosis of non-alcoholic fatty liver disease (NAFLD) was based on elevated ALT levels and hepatic steatosis on USG records (11). The diagnosis of suspected drug-induced liver injury (DILI) (hepatocellular type injury) is defined by ALT > 2 ULN (upper limits of normal) in the patients with history of drug exposure and in whom other possible etiologies were excluded ${ }^{12}$.

The severity of hypertransaminasemia was categorized as mild $(<5$ fold of ULN), moderate (between 5 to 10 fold of ULN) and severe (> 10 fold of ULN) ${ }^{13}$.

The etiology, severity of hypertransaminasemia, normalization status were re-evaluated for four different age groups as following; <2 years, 2-5 years, $>5-12$ years, and $>12$ years.

The Local Clinical Research Ethics Committee of our hospital approved the study (desicion number:2013-147). 
Statistical analyses were performed using Statistical Package for Social Science (SPSS) software (ver. 11.0). Results are presented as means \pm SDs with descriptive statistics if distrubition of variances were normal, median (minimummaximum) values were given if the distrubition of variances weren't normal. The Student's unpaired t-test was used as appropriate. When the variances were unequal or the distributions not normal, the Mann-Whitney U-test and $\mathrm{X}^{2}$-test were used as appropriate.The significance level was set at $\mathrm{p}<$ 0.05 .

\section{RESULTS}

Demographic characteristics and medical history

Of the 292 patients, $194(66.4 \%)$ were male and 98 $(33.6 \%)$ were female. The mean age was $6.5 \pm 5.4$ years old (3months-18 years) and didn't differ according to the gender $(\mathrm{p}>0.05)$.

At the time of admission, $45.9 \%$ of the patients had no complaints. At least one of the following complaints were present in 158 patients; obesity (29.1\%), fever (23.4\%), abdominal pain (12.7\%), vomiting (12.7\%), anorexia (6.3\%), diarrhea $(5.7 \%)$, constipation $(3.8 \%)$, fatigue $(2.5 \%)$, poor weight gain $(2.5 \%)$ and abdominal distension $(1.3 \%)$.

The medical history revealed drug usage in 30 $(10.3 \%)$ patients. These drugs were antibiotics (50\%), antiepileptics (20\%), colchium (13.3\%), nonsteroid anti-inflammatory drugs (10\%), isoniazid $(3.3 \%)$ and steroid $(3.3 \%)$. None of patients had a history of herbal consumption and contact with suspicious material that carry the risk of viral hepatitis transmision. Twenty-eight $(9.6 \%)$ children had an infection history as following; upper respiratory tract infection (71.4\%), urinary tract infection $(17.9 \%)$ and acute otitis media $(10.7 \%)$.

The family history revealed consanguinity among parents in $36(12.3 \%)$ patients. Liver steatosis (9), chronic Hepatitis B virus (HBV) infection ${ }^{8}$, Wilson's disease ${ }^{4}$, muscle disease ${ }^{2}$, autoimmune hepatitis ${ }^{1}$, cholelithiasis ${ }^{1}$ were present in the family members.

\section{Physical examination findings}

Of the 292 patients, 222 (76\%) had normal physical examination findings. Sixty-one $(20.8 \%)$ patients had hepatomegaly and 9 (3\%) patients had splenomegaly, but none of the patients had icterus, ascites and other chronic liver disease findings.

Among the patients 71 (24.3\%) were obese, 16 $(5.4 \%)$ were overweight and 38 (13\%) had wasting.
The etiologic evalution of hypertransaminasemia

The mean ALT value was 164.9 \pm 319.3 IU/L (14$4931 \mathrm{IU} / \mathrm{L}$ ), and the mean AST value was $156.2 \pm 417.3 \mathrm{IU} / \mathrm{L}(27-6470 \mathrm{IU} / \mathrm{L})$. The males had higher mean AST levels than females $(158 \pm 493$ and $152 \pm 197.1 \mathrm{IU} / \mathrm{L}$, respectively) ( $\mathrm{p}=0.015)$.

The severity of hypertransaminasemia was mild in $238(81.6 \%)$ patients, modarete in $34(11.6 \%)$ patients and severe in $20(6.8 \%)$ patients.

None of the patients had serologic findings of acute hepatitis A virus (HAV) (0/262), hepatitis C virus (HCV) (0/274), HIV (0/272), toxoplasma (0/219) and rubella infections $(0 / 218)$. The other infections are shown in Table 1.

Abdominal USG was performed in 278 (95.2\%) patients; 137 (49.2\%) had normal findings, 108 (38.8\%) had hepatomegaly, $80(28.7 \%)$ had hepatic steatosis, $34(12.2 \%)$ had splenomegaly, $16(5.7 \%)$ patients had heterogenecity on liver parenchyma, $6(2.1 \%)$ had gallstones.

Seventeen patients underwent liver biopsy. Chronic active hepatitis (12), micronoduler cirhosis (1), steatohepatitis (1), fibrosis (2), normal liver histopathology (1) were revealed.

None of the patients had elevated serum ferritin level $(0 / 106)$ and positive sweat chloride test (0/56).

In 191 (65.4\%) children the etiology of hypertransaminasemia was identified detected (Table 1). NAFLD was the most common cause of hypertransaminasemia in the study group.

The characteristics of hypertransaminasemia according to etiology was shown in Table 2.

Of the cases diagnosed with NAFLD, 66 (\%88) were obese and $2(2.7 \%)$ were overweight. Seven (9.3\%) children with NAFLD were in normal weight; 2 of them diagnosed with hereditary fructose intolerance (HFI). According the diagnoses NAFLD patients hadthe highest mean age $(p<0,001)$. The mean ALT levels was higher than AST levels in patients with NAFLD $(p<0.001)$. Both the mean AST and ALT levels of NAFLD patients were lower than the other diagnoses $(p<0.001$ and $p=0.036$ respectively) (Table 2).

The patients diagnosed with infectious diseases were younger than the patients with other specific diagnoses $(p=0.02)$. There was no difference in between the other etiologies in terms of mean age, ALT and AST levels except outlined above (Table 2). 
Table 1:The etiology of hypertransaminasemia in the study group

\begin{tabular}{|c|c|c|}
\hline & $\mathrm{N}$ & $\%$ \\
\hline Idiopathic & 101 & 34.5 \\
\hline Non-alcoholic fatty liver disease & 75 & 25.7 \\
\hline Infectious diseaes & 46 & 15.7 \\
\hline Hepatitis B virus & 13 & \\
\hline Cytomegalovirus & 23 & \\
\hline Ebstein-Barr virus & 7 & \\
\hline Adenovirus & 1 & \\
\hline Varicella-zoster virus & 1 & \\
\hline Brucella & 1 & \\
\hline Drug induced liver injury & 24 & 8.2 \\
\hline Amoxicillin and clavulanic acid & 5 & \\
\hline Cephalsporines & 6 & \\
\hline Ampicillin/sulbactam & 2 & \\
\hline Isoniazid & 1 & \\
\hline Colchicine & 4 & \\
\hline Nonsteroid anti-inflammatory drugs & 3 & \\
\hline Carbamazepine & 1 & \\
\hline Valproic acid & 1 & \\
\hline Steroids & 1 & \\
\hline Metabolic/Genetic diseases & 15 & 5.1 \\
\hline Wilson's disease & 10 & \\
\hline Hereditary fructose intolerance & 2 & \\
\hline Alpha-1 antitrypsin deficiency & 2 & \\
\hline Pompe disease & 1 & \\
\hline Elevated creatine kinase levels/Muscle & 16 & 5.4 \\
\hline Muscular dystrophy & 8 & \\
\hline Autoimmune hepatitis & 3 & 1.0 \\
\hline Hypothyroidism & 4 & 1.4 \\
\hline Celiac disease & 2 & 0.6 \\
\hline Cholecyctitis & 6 & 2.0 \\
\hline
\end{tabular}

The characteristics of the patients with an identified etiology and unknown etiology was shown in Table 3 . The patients with identified etiology were older $(\mathrm{p}<0.0001)$ and had lower mean AST value $(\mathrm{p}=0.008)$ than patients with unknown etiology (Table 3 ). 
Table 2: Comprasion of age of the patients, severity of hypertransaminasemia and normalization time of transaminases according to the etiologies

\begin{tabular}{|l|c|c|c|c|c|}
\hline & NAFLD & $\begin{array}{c}\text { Infectious } \\
\text { diseases } \\
(\mathrm{N}: 46)\end{array}$ & $\begin{array}{c}\text { DILI } \\
(\mathrm{N}: 24)\end{array}$ & $\begin{array}{c}\text { Muscle } \\
\text { diseases } \\
(\mathrm{N}: 16)\end{array}$ & $\begin{array}{c}\text { Metabolic/Genetic } \\
\text { diseases } \\
(\mathrm{N}: 15)\end{array}$ \\
\hline $\begin{array}{l}\text { Age (months) } \\
(\text { mean } \pm \text { SD) }\end{array}$ & $133.9 \pm 42.1$ & $57 \pm 64$ & $87.6 \pm 64.5$ & $82.7 \pm 58.7$ & $80.1 \pm 51.2$ \\
\hline $\begin{array}{l}\text { AST (IU/l) } \\
(\text { mean } \pm \text { SD) }\end{array}$ & $63.9 \pm 35.1$ & $148 \pm 134.8$ & $127 \pm 122$ & $247 \pm 180.3$ & $142 \pm 99.5$ \\
\hline $\begin{array}{l}\text { ALT (IU/l) } \\
(\text { mean } \pm \text { SD) }\end{array}$ & $103.4 \pm 62.1$ & $163.3 \pm 152.8$ & $144 \pm 150$ & $203.5 \pm 101.4$ & $174 \pm 130.5$ \\
\hline $\begin{array}{l}\text { Mild } \\
\text { hypertransaminasemia } \\
\text { (N, \%) }\end{array}$ & $72(94.6)$ & $32(69.6)$ & $20(83.3)$ & $12(75)$ & $9(60)$ \\
\hline $\begin{array}{l}\text { Mean normalization } \\
\text { time (months) }\end{array}$ & $5.9 \pm 4.6$ & $5.8 \pm 4.4$ & $2.7 \pm 1.1$ & - & $7.4 \pm 3.9$ \\
\hline
\end{tabular}

NAFLD: Non-alcoholic fatty liver disease, DILI: Drug induced liver injury, AST: Aspartate aminotransferase, ALT:

Alanine aminotransferase

Table 3: The comparision of the patients with and without certain etiology

\begin{tabular}{|l|l|l|l|}
\hline & $\begin{array}{l}\text { Identified etiology } \\
(\mathrm{N}: 191)\end{array}$ & $\begin{array}{l}\text { Unidentified etiology } \\
(\mathrm{N}: 101)\end{array}$ & P value \\
\hline Age (months) (mean \pm SD) & $97 \pm 62$ & $47.5 \pm 57$ & $<0.0001$ \\
\hline ALT (IU/l) (mean \pm SD) & $139.8 \pm 125$ & $202.2 \pm 489$ & N.S. \\
\hline AST (IU/l) (mean \pm SD) & $117.2 \pm 113$ & $219.5 \pm 65.5$ & 0.008 \\
\hline Normalization time (months) & $5.3 \pm 4.1$ & $5.1 \pm 5.1$ & N.S. \\
\hline
\end{tabular}

ALT: Alanine aminotransferase, AST: Aspartate aminotransferase, N.S: Non significant

Course of the transaminase levels

The transaminase levels were normalized in 118 (40.4\%) patients at mean $5.3 \pm 4.4$ (range: $2-21$ ) months, of them $86 \quad(72.8 \%)$ achieved normalization in less than 6 months.

The patients who had normalization of transaminases were older than others (mean age $88 \pm 65.9$ months vs $71.7 \pm 64.3$ months, respectively $(\mathrm{p}=0.03)$.

There were no significant difference in normalization status and normalization period according to the severity of hypertransaminasemia and gender $(\mathrm{p}>0.05)$.

Normalization of transaminases were determined in $82(45.5 \%)$ patients with known etiology and 36 $(32.2 \%)$ patients with unknown etiology. The normalization period of the patients with or without a known etiologic factor were similar to each other
(Table3).

The normalization status did not differ according to the etiological factors, except the patients with DILI who had an shortest normalization time $(2.7 \pm 1.1$ months) than all other diagnoses $(\mathrm{p}=0.015)$ (Table 2$)$.

The most common diagnoses in the patients who had elevated transaminases for 6 months or more were NAFLD and genetic/metabolic disorders.

Hypertransaminasemia according to age groups

The comparison of age groups in terms of mean ALT and AST values, etiology, normalization status and normalization time were presented in Table 4.

One hundred twenty-six (66\%) of the patients with known etiology were older than 5 years old and the $75 \%$ of the patients with unknown etiology were younger than 5 years old.

The mean AST levels of patients younger than 5 
years-old were significantly higher than patients older than 5 years-old $(\mathrm{p}<0.001)$ (Table 4).

Twenty-four $(52.1 \%)$ patients diagnosed with infectious diseases were younger than 2 years-old.
Seventy-one patients with NAFLD (94.6\%) were older than 5 years-old (Table 3 ).

Table 4: The comparison of age groups in terms of mean ALT and AST values, normalization status and etiologies

\begin{tabular}{|l|c|c|c|c|}
\hline & \multicolumn{4}{|c|}{ Age groups } \\
\cline { 2 - 5 } & $\begin{array}{l}<2 \text { years old } \\
(\mathrm{N}=99)\end{array}$ & $\begin{array}{l}2-5 \text { years old } \\
(\mathrm{N}=44)\end{array}$ & $\begin{array}{l}5-12 \text { years old } \\
(\mathrm{N}=91)\end{array}$ & $\begin{array}{l}>12 \text { years old } \\
(\mathrm{N}=58)\end{array}$ \\
\hline $\begin{array}{l}\text { ALT (IU/l) } \\
(\mathrm{mean} \pm \mathrm{SD})\end{array}$ & $187.6 \pm 498.3$ & $256.2 \pm 268.1$ & $127.3 \pm 112.7$ & $116.3 \pm 86.8$ \\
\hline $\begin{array}{l}\text { AST (IU/l) } \\
(\text { mean } \pm \text { SD) }\end{array}$ & $200.5 \pm 646.7$ & $250.2 \pm 377.8$ & $113 \pm 155.4$ & $76.8 \pm 70.2$ \\
\hline Normalization of transaminases & $33(33.3 \%)$ & $17(38.6 \%)$ & $38(41.8 \%)$ & $30(51.7 \%)$ \\
\hline Certain etiology (N: 191$)$ & $42(22 \%)$ & $23(12 \%)$ & $76(39.8 \%)$ & $50(26.2 \%)$ \\
\hline NAFLD (N: 75) & $3(4 \%)$ & $1(1.3 \%)$ & $41(54.6 \%)$ & $30(40 \%)$ \\
\hline Infectious diseases (N: 46) & $24(52.2 \%)$ & $5(10.9 \%)$ & $10(21.7 \%)$ & $7(15.2 \%)$ \\
\hline DILI (N: 24) & $5(20.8 \%)$ & $5(20.8 \%)$ & $9(37.5 \%)$ & $5(20.8 \%)$ \\
\hline $\begin{array}{l}\text { Metabolic/Genetic diseases } \\
(\mathrm{N}: \text { 15) }\end{array}$ & $3(20 \%)$ & $2(13.3 \%)$ & $8(53.3 \%)$ & $2(13.3 \%)$ \\
\hline AIH (N: 3) & - & - & $3(100 \%)$ & - \\
\hline Others (N: 28) & $7(25 \%)$ & $10(35.7 \%)$ & $5(17.9 \%)$ & $6(21.4 \%)$ \\
\hline
\end{tabular}

ALT: Alanine aminotransferase, AST: Aspartate aminotransferase, NAFLD: Non-alcoholic fatty liver disease, DILI: Drug induced liver injury, AIH: Autoimmune hepatitis

\section{DISCUSSION}

In previous studies, the prevelance of the conditions related to hypertransaminasemia differed due to the study population. Whether some of them included HAV infections, some of them excluded obesity, hepatotropic virus infections or drug usage ${ }^{4-7}$. They reported that most common causes of elevated transaminases were infections (31.2\%-34\%) and obesity related NAFLD (17.6\%$11.1 \%)^{5,6}$. We determined NAFLD $(25.7 \%)$ and infectious diseases $(15.7 \%)$ were the common causes. Despite HAV infection is the leading infectious causes of acute hepatitis in our country ${ }^{6}$, due to its cholestatic pattern, there wasn't any patient in our study. So the prevelance of infectious disease was found as the second frequent cause of hypertransaminasemia or may be the result of increased childhood obesity rates in recent years NAFLD is frequently associated with childhood obesity ${ }^{14}$. The prevalence of fatty liver disease in obese children has been reported to be between $10 \%$ and $77 \%{ }^{15-19}$. In our study, $66(93 \%)$ of 71 obese children had NAFLD. It was shown that the frequency of NAFLD increased with age; such as NAFLD reported to be in $0.7 \%$ between age of 2-4 years and in $17.3 \%$ between age of $12-15$ years ${ }^{19}$. Similarly, we showed that NAFLD increased with age, only $5.3 \%$ of NAFLD patients were younger than 5 years old and $51.7 \%$ of them older than 12 years old. Also similar to the previous studies, we found mildly elevated ALT levels, and elevation of ALT is higher than AST ${ }^{20,21}$.

The frequency of NAFLD in normal weight children was reported as $5-20 \%$ and metabolic diseases should be considered ${ }^{21}$. We demontrated 2 children with NAFLD within normal weight had hereditary fructose intolerance.

The most common causes of viral hepatitis are hepatotropic virus infections (90\%) and the remaning ones are due to non-hepatotropic virus infections like Cytomegalovirus (CMV) and Epstein-Barr virus (EBV) ${ }^{22}$. Ioro et al.(5) reported that the viral infections $(31.2 \%)$ were the most common causes of hypertransaminasemia, despite excluding of the hepatotropic viruses from the study. EBV (62.4\%) and CMV (31.5\%) were the most common non-hepatotropic virus infections in their study (5). In our study, the most common viral agents were CMV (50\%), HBV (28.2\%) and EBV $(15.2 \%)$. We thought that this difference of our findings from the literature may be due to vaccination programs for $\mathrm{HBV}$ in our country and exclusion of HAV infections. 
Many drugs may alter liver functions and liver toxicity may be seen in various forms; ranging from mild transaminase elevation to fulminant hepatitis ${ }^{23}$. The DILI was reported as a cause of elevated transaminases $(18.1 \%-3 \%)$ in different studies ${ }^{5,6,24}$. Our diagnosis of DILI was $8.2 \%$ and mostly related to antibiotic usage.It may be a result of higher rates of antibiotic usage in our country. Similar to the previous studies ${ }^{25,26}$, amoxicillinclavulanic acid was the one of the most common associated antibiotic with DILI. Also the mean normalization time of patients with DILI was the most shorter period compared to others.

Most of the genetic/metabolic diseases alter liver functions. Iorio et al. found that genetic/ metabolic disorders were responsible about $12 \%$ of hypertransaminasemia and most common diagnoses were Wilson's disease (4.2\%) ${ }^{5}$. In our study the frequency of genetic/metabolic disorders was $5.1 \%$. The most frequent metabolic/genetic disease was Wilson's disease (3.4\%). Also rare genetic/metabolic disease as hereditary fructose intolerance and Pompe disease were diagnosed with appropiate tests. The low rate of our metablic disease may be due to excluding cholestatic patients, age range and limited genetic tests.

Liver enzyme abnormalities are common in thyroid diseases. Hypothyroidism cause a mild to moderate increase in transaminase levels ${ }^{27}$. In our study, we detected hypothyroidism in $1.4 \%$ of the cases. Transaminase elevation was mild to moderate and on follow-up, under hormone replacement treatment, transaminases were normalized.

Autoimmune hepatitis (AIH) may be presented with asymptomatic hypertransaminasemia but early diagnosis and treatment should be made due to the potential of rapid progression, even in fulminant liver failure ${ }^{28}$. In several studies, AIH was responsible for 1.6-2.5\% of hypertransaminasemia ${ }^{5,29}$. In our study, $1 \%$ of the children diagnosed with $\mathrm{AIH}$ and transaminases were normalized with treatment in all cases.

Liver enzymes may be elevated due to muscle disorders. Because of the accessibility of CK level measurement, it should be evaluated in the first step examination of hypertransaminasemia. Ioro et al(5). reported, $3.2 \%$ of children with hypertransaminasemia had muscular dystrophy ${ }^{5}$. In our study, hypertransamiansemia was related with muscle disease involvement in $5.4 \%$ of children, of them $2.7 \%$ had muscular dystrophy.

Celiac disease is a common inflammatory enteropathy in genetic predisposing patients and may be presented in various forms. Asymptomatic patients may be presented with asymptomatic hypertransaminasemia incidentally. We determined $0.6 \%$ of patients had celiac disease without any symptoms.

The etiology of transaminase elevation may not always be identified. In the study by Çeltik et al. ${ }^{4}$ which included only hospitalized patients, the idiopathic rate was found to be $27.1 \%$. In the anorther study from Turkey, the causes could not be determined in $18(6.4 \%)$ of the patients ${ }^{6}$. We could not identify the etiology in 109 (37.3\%) patients, despite appropiate laboratory, genetic tests and histopathological evaluation.

We studied whether the severity of hypertransaminase levels vary according to the underlying disease. We determined that patients with toxic hepatitis and acute viral hepatitis had more severe hypertransaminasemia and patients with the NAFLD had more mild hypertransaminasemia.

In our study, the normalization rate was $40.4 \%$ in mean $5.3 \pm 4.4$ months. We found that the rate of normalization in diagnosed cases $(45.5 \%)$ was significantly higher than those undiagnosed (32.2\%), which may be related to the treatment and natural course of self limiting infections. Transaminase normalization did not correlate with gender, grade of transaminase elevation and age groups. In children with persistent hypertransaminases longer than 6 months, most common diagnoses were NAFLD and genetic conditions ${ }^{5}$. Similarly, we found NAFLD was common in patients who had hypertransaminasemia longer than 6 months.

The limitations of our study are as following; being a retrospective study, only patients who admitted to our outpatient clinic, not studying macro-AST, and lost of the patients on follow-up, not study macroAST.

\section{CONCLUSION}

Many liver and non-liver diseases cause transaminase elevation in children. The NAFLD and infections were the most common diagnoses. The severity of hypertransaminasemia, age group of the patients, a careful medical and family history may lead the correct stepwise approach to diagnose. The patients who are undiagnosed should be follow-up for normalization of transaminases and further diagnostic tests like whole exome sequence analysing should be planned according to the course of transaminases.

\section{REFERENCES}

1. Vajro PM, Maddoluno S, Veropalumbo C. Persistent hypertransaminasemia in asymptomatic 
children: A stepwise approach. World J Gastroenterol 2013; 14; 19: 2740-2751.

2. Rook M, Rosenthal P. Caring for adults with pediatric liver disease. Curr Gastroenterol Rep 2009; 11: 83-89 [PMID: 19166664 DOI: 10.1007/s11894-009-0013-7]

3. Hyun HJ, Shim JJ, Kim JW, Lee JS, Lee CK, Jang JY, et al. The prevalence of elevated alanine transaminase and its possible causes in the general Korean population. J Clin Gastroenterol 2014; 48(6):534-539.

doi:

10.1097/MCG.0b013e3182a474d3

4. Çeltik C, Erbaş H, Kurşun ÖS, Bostancioğlu M, İnan $\mathrm{M}$, Öner $\mathrm{N}$ et al. The Reasons of Elevated Serum Transaminases in Childhood [Article in Turkish]. Turk J Biochem 2008; 33(4):175-181.

5. Iorio R, Sepe A, Giannattasio A, Cirillo F, Vegnente A. Hypertransaminasemia in childhood as a marker of genetic liver disorders. J Gastroenterol 2005; 40: 820-826.

6. Serdaroglu F, Koca T, Dereci S, Akcam M. The etiology of hypertransaminasemia in Turkish children.. Bosn J Basic Med Sci. 2016;16(2):151156.

7. Bugeac N, Pacht A, Mandel H, Iancu T, Tamir A, Srugo I, et al. The significance of isolated elevation of serum aminotransferases in infants and young children. Arch Dis Child 2007; 92(12):1109-1112.

http://dx.doi.org/10.1136/adc.2007.121194

8. Ahmar Shamim, Nimain C. Mohanty. Etiological Spectrum of Children Presenting With Raised Liver Transaminases and Their Outcome in a Tertiary Care Pediatric Facility at Navi Mumbai, India. Clinical Gastroenterology and Hepatology 2015; Vol. 13, No. 7.

9. Krebs NF, Himes JH, Jacobson D, Nicklas TA, Guilday P, et al. (2007) Assessment of child and adolescent overweight and obesity. Pediatrics 120: S193-S228.

10. Cole TJ, Bellizzi MC, Flegal KM, Dietz WH (2000) Establishing a standard definition for child overweight and obesity worldwide: international survey. BMJ 320: 1240-1243.

11. Fishbein MH, Miner M, Mogren C, Chalekson $\mathrm{J}$. The spectrum of fatty liver in obese children and the relationship of serum aminotransferases to severity of steatosis. J Pediatr Gastroenterol Nutr 2003; 36(1):54-61. http://dx.doi.org/10.1097/00005176-20030100000012 .
12. Tajiri K, Shimizu Y. Practical guidelines for diagnosis and early management of drug-induced liver injury. World J Gastroenterol 2008; 14(44):6774-6785.

http://dx.doi.org/10.3748/wjg.14.6774

13. Gilbert-Barnes E, Barness LA, Farrell PM. Clinical Use of Pediatric Diagnostic Tests. 6th ed. Philadephia. Lippincott Williams, Wilkins. 2003; 20-56.

14. Schwimmer JB, Deutsch R, Kahen T, Lavine JE, Stanley C. Prevalence of fatty liver in children and adolsecents. Pediatr 2006; 118: 1388-1393.

15. Franzese A, Vajro P, Argenziano A, Rubino A, Brunetti F, Saviano MC, et al. Liver involvement in obese children. Ultrasonography and liver enzyme levels at diagnosis and during follow-up in an Italian population. Dig Dis Sci. 1997;42:1428 1432

16. Tazawa $Y$, Noguchi H, Nishinomiya F, Takada G. Serum alanine aminotransferase activity in obese children. Acta Pediatr. 1997;86:238 -241

17. Strauss RS, Barlow SE, Dietz WH. Prevalence of abnormal serum aminotransferase values in overweight and obese adolescents. J Pediatr. 2000;136:727-733

18. Chan DF, Li AM, Chu WC, Chan MH, Wong EM, Liu EK, et.al. Hepatic steatosis in obese Chinese children. Int J Obes Relat Metab Disord. 2004;28:1257- 1263

19. Rafeey M, Mortazavi F, Mogaddasi F, Robabeh G, Ghaffari S, Hasani A. Fatty liver in children. Ther Clin Risk Manag 2009; 5: 371-374.

20. Purcell M, Flores YN, Zhang ZF, DenovaGutiérrez E, Salmeron J. Prevalence and predictors of alanine aminotransferase elevation among normal weight, overweight and obese youth in Mexico. J Dig Dis 2013; 14(9):491-499. http://dx.doi.org/10.1111/1751-2980.12072.

21. Yap JYK, Connor OC, Mager DR, Taylor G, Roberts EA. Diagnostic challenges of NAFLD in children of normal weight. Hepatol and Gastroenterol 2011; 35: 500-505.

22. Paulina Cybulska, Andy Ni, Carolina Jimenez-Rivera. Viral Hepatitis: Retrospective Review in a Canadian Pediatric Hospital. ISRN Pediatrics Volume 2011, Article ID 182964, 4 pages doi:10.5402/2011/182964

23. Larrey D. Drug induced liver disease. J Hepatol 2000; 32: 77-78. 
24. Bjornsson E, Olsson R. Outcome and prognostic markers in severe drug induced liver disease. Hepatol 2005; 42: 481-489.

25. Pandit A, Sachdeva T, Bafna P. Drug-Induced Hepatotoxicity: A Review. JAPS 2012; 02: 233243.

26. Chalasani N, Fontana RJ, Bonkovsky HL, Watkins PB, Davern T, Serrano J, et al. Causes, clinical features, and outcomes from a prospective study of drug-induced liver injury in the United States. Gastroenterology. 2008;135:1924-1934. 1934 e1921-1924.
27. Burra P, Lecturer S. Liver abnormalities and endocrine diseases. Clin Gastroenterol 2013; 27: 553-563.

28. García Romero R, Martín de Carpi J, Bernal Cuartas C, Pinillos Pisón S, Varea Calderón V. Autoimine hepatitis in pediatric patients. Rev Esp Enferm Dig 2007; 99 255-258.

29. Clark J, Brancati F, Diehl A. The prevelance and etiology of elevated aminotransferase levels in the United States. Am J Gastroenterol 2003; 98: 960-967. 